\title{
Effect of an adequate-protein diet after a low-protein diet on protein catabolism in growing rats
}

\author{
BY YOSHIMITSU HORIE* AND KIYOSHI ASHIDA \\ Laboratory of Nutritional Biochemistry, Department of Agricultural Chemistry, \\ Nagoya University, Chikusa, Nagoya, Japan
}

(Received 7 October 197I - Accepted 4 fuly 1972)

\begin{abstract}
I. Metabolic alterations related to protein catabolism were studied in rats in transitional states induced by changing from a low-protein (LP) ( $5 \circ \mathrm{g}$ casein $/ \mathrm{kg}$ ) diet to a high-protein (HP) (250 g casein $/ \mathrm{kg})$ diet.

2. Twenty-four hours after the diet was changed, the rats showed a more rapid increase in live-weight gain than controls that had been fed on the HP diet throughout. On the $5^{\text {th }}$ day after the diet change, their increase in body-weight had returned almost to the control rate. Food and therefore nitrogen intakes on the ist and 5 th days after the change in diet were the same as those of the controls. It seems likely therefore that the initial high rate of live-weight gain is an indication of a metabolic adaptation which occurred on the LP diet and which did not fully return to normal until the $5^{\text {th }}$ day after the change of diet.

3. $\mathrm{N}$ balance was higher $24 \mathrm{~h}$ after the change in diet than in the controls, owing to a reduction in total urinary $N$ and in urea excretion, but when measured on the 5 th day it was similar in both groups.

4. Carcass $\mathrm{N}$ determination showed that, after $7 \mathrm{~d}$ on the LP diet total-, trichloroacetic acid (TCA)-soluble- and TCA-insoluble-N contents (in terms of $\mathrm{mg} / \mathrm{g}$ rat) were all slightly lower than control values but they had almost returned to normal $5 \mathrm{~d}$ after the diet change. There was a significant increase in the TCA-soluble-N content after $24 \mathrm{~h}$ on the HP diet to a value greater than the control value.

5. Proteolysis was measured in vitro by incubation of liver slices and diaphragms under anaerobic conditions. Withliver slices it was significantly lower 24 hafter the diet change than in control rats. On the $5^{\text {th }}$ day it was significantly higher than $24 \mathrm{~h}$ after the diet change but had not quite reached the control level. In the diaphragm, proteolysis was also lower I $\mathrm{d}$ after the diet change, and had not increased at all by the 5 th day.

6. Ureogenesis in the liver was reduced significantly $24 \mathrm{~h}$ after the diet change and it had almost returned to the control level on the 5 th day. $\mathrm{On}$ the other hand, arginase (L-arginine amidinohydrolase; $E C 3 \cdot 5 \cdot 3 . \mathrm{I}$ ) activity was significantly lower $24 \mathrm{~h}$ after the diet change and did return completely to the control level on the 5 th day.

7. These results show that the initial increased $\mathrm{N}$ balance and reduced $\mathrm{N}$ excretion were due to enzymic adaptation to the LP diet, the reduced $N$ excretion being attributable to reduction in hepatic urea production.
\end{abstract}

Important problems in nutrition are how animals respond to a new diet and the nature of the metabolic changes that occur during adaptation. Mendes \& Waterlow (I958) reported that, when growing rats were transferred from a low-protein (LP) diet to a stock diet, they increased in body-weight more rapidly than control rats, particularly for the first few days after the diet change. Their rate of increase in bodyweight gradually returned to the control level in the next few days. Thus the animals apparently took a certain length of time to become adapted to the stock diet. To investigate the biochemistry of the transitional state in adapting to a new diet, we fed one group of rats on a LP diet for $7 \mathrm{~d}$ and then transferred them to a high-protein diet

* Present address: Laboratory of Nutrition, Department of Life Science, Nagoya Municipal Junior Women's College, Chikusa, Nagoya, Japan. 
(HP), the control group receiving the latter diet throughout. We have studied protein metabolism by measuring changes in nitrogen excretion in the urine, by carcass analysis, by measuring the rate of proteolysis in liver and muscle and by studying arginase activity and the rate of urea production in the liver.

\section{EXPERIMENTAL}

\section{Plan of experiments}

The animals and diets were the same as those previously described (Horie \& Ashida, I971). Weanling rats were fed on a HP diet, containing $25^{\circ} \mathrm{g}$ casein $/ \mathrm{kg}$, until they attained a body-weight of $75-85 \mathrm{~g}$. Then they were divided into two groups. One group was fed on the HP diet throughout and served as controls. The other group was fed on a LP diet, containing $5 \circ \mathrm{g}$ casein $/ \mathrm{kg}$, for $7 \mathrm{~d}$ and then on the HP diet for 5 or $6 \mathrm{~d}$. Immediately before being given to the animals, the food was kneaded with water into a soft ball to prevent scattering and to enable an exact record of food intake to be made. For $\mathrm{N}$ determination in the carcasses, animals were killed at i 8.00 hours with chloroform vapour, and the carcasses were immediately frozen and stored at $-20^{\circ}$ until analysed. For other purposes, animals were killed by decapitation: they were not starved before killing.

\section{$N$ determination in the carcasses}

'The frozen carcasses were cut into pieces and minced by passing several times through a manual meat grinder at a room temperature of $10-15^{\circ}$. The intestinal contents were not removed since it was found that the intestinal $\mathrm{N}$ contents of rats in all groups were very small at the time of death (at most, Io $\mathrm{mg}$ ). The method for $\mathrm{N}$ determination was the same as that used by Horie \& Ashida (I97I) for liver.

\section{Measurement of $N$ balance}

Animals were fed from 18.00 hours on one day to 18.00 hours on the next day, and their faeces and urine during this period were collected and analysed for $\mathrm{N}$ by the semi-micro-Kjeldahl method. $N$ intake for the period was calculated from the amount of food eaten and its $\mathrm{N}$ content, and $\mathrm{N}$ retention as the difference between $\mathrm{N}$ intake and $\mathrm{N}$ excretion.

\section{Measurement of urea in the urine}

Samples of urine were suitably diluted with water and urea was determined colorimetrically by the method of Archibald (r945).

\section{Proteolysis in the liver and diaphragm in vitro}

After decapitation of the rats, the livers were quickly removed and sliced, about $0.5 \mathrm{~mm}$ thick, with a razor-blade. A sample of the slices was immediately treated with trichloroacetic acid (TCA) to serve as a zero-time control. Another sample of the slices was placed in a Thunberg tube containing I $\mathrm{ml}$ of Britton-Robinson buffer (Britton \& Robinson, $193 \mathrm{I}$ ), $\mathrm{pH} 77^{\circ}$, and incubated at $37^{\circ}$ for 4 h under $\mathrm{N}_{2}$. Reactions 
were stopped by addition of $3 \mathrm{ml}$ of TCA $(100 \mathrm{~g} / 1)$ and the contents of the tube were filtered. A portion of the filtrate was taken for determination of materials giving a Folin-Ciocalteu phenol reaction (Anson \& Mirsky, 1932-3), using tryptophan as a standard. Proteolysis was expressed as $\mu \mathrm{mol}$ tryptophan equivalents per $\mathrm{g}$ tissue or per total organ. Portions of diaphragm were placed in $50 \mathrm{ml}$ conical flasks containing the same buffer as for the liver and incubated under similar conditions, except that the flasks were shaken at roo cycles/min. Subsequent treatments were the same as for liver except that the contents of the flask were thoroughly homogenized with a glass homogenizer before filtration.

Some other experiments were made with liver homogenates. The liver was homogenized with 5 volumes of the buffer, and then incubated to determine the increase in amino acids released as a measure of proteolysis. The reactions in both control and incubated samples were stopped with pictic acid ( $10 \mathrm{~g} / \mathrm{l})$ by the method of Stein \& Moore (1954). After removal of the picric acid, amino acids were determined with a Beckman, Model I2oB (Beckman Instrument Co. Inc., Fullerton, California), amino acid analyser.

\section{Ureogenesis and arginase activity of the liver}

The rate of urea production by liver slices was determined by the method of Metz, Salter \& Brunet ( 1968 ) except that $\mathrm{NH}_{4} \mathrm{Cl}$ was not added to the incubation medium. A sample of liver slices was placed in a $5^{\circ} \mathrm{ml}$ conical flask containing $2 \mathrm{ml}$ KrebsHenseleit buffer, $\mathrm{pH} 7 \cdot 4$, and incubated at $37^{\circ}$ for $\mathrm{I} \cdot 5 \mathrm{~h}$ under $\mathrm{O}_{2}-\mathrm{CO}_{2}(95: 5)$ with shaking at 100 cycles/min. Incubations were conducted in triplicate. The reaction was stopped with TCA, the contents of the flask were filtered and urea was determined. The activity of arginase (L-arginine amidinohydrolase; $E C_{3} \cdot 5 \cdot 3.1$ ) was measured by the method of Schimke ( 1962 ). Reaction mixture containing $0.5 \mathrm{ml} 0.5 \mathrm{M}$-L-arginine $(\mathrm{pH} 8.5)$ and $0.5 \mathrm{ml}$ diluted enzyme preparation was incubated at $37^{\circ}$ for $10 \mathrm{~min}$. Urea was determined by the method of Archibald (1945).

\section{RESULTS AND DISCUSSION}

\section{Changes in body-zweight}

On the Ist day of the change from the LP diet to the HP diet the rats increased significantly more in body-weight than control rats that had been fed on the HP diet throughout. On the $5^{\text {th }}$ day after the change these rats showed the same increase in body-weight as controls. These findings are essentially in agreement with those of Mendes \& Waterlow (1958). In our experiments, we had no corresponding controls of the ' $5 \mathrm{~d}$ ' experimental rats, but used the ' $I \mathrm{~d}$ ' controls as the ' $5 \mathrm{~d}$ ' controls, since in other experiments, rats which had been fed on the HP diet throughout showed almost the same increase in body-weight $(5-7 \mathrm{~g} / \mathrm{d}$ per rat) throughout the test period.

Food intake, expressed as $\mathrm{g} / \mathrm{d}$ per rat, was the same on the Ist and $5^{\text {th }}$ days after the diet change as in control rats. However, for $24 \mathrm{~h}$ after the diet change the test animals ate more than the controls on a body-weight basis since the rats that had been given the LP diet for $7 \mathrm{~d}$ weighed less $(75 \pm 2.4 \mathrm{~g} \mathrm{SD})$ than the controls ( $112 \pm 2.5 \mathrm{~g}$ ). On the $5^{\text {th }}$ day they ate the same amount as the $\mathrm{I} d$ controls. The rapid increase in 
है :

$\therefore$

羽

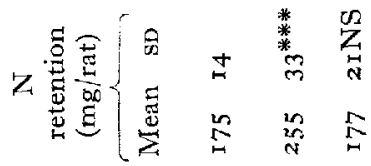

ร

$\sum_{1}^{2}$

है

ह

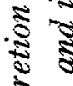

胥 :

章

敢

8.

용

正

可

ญั

$\approx$

ำ

疍

ปี

8

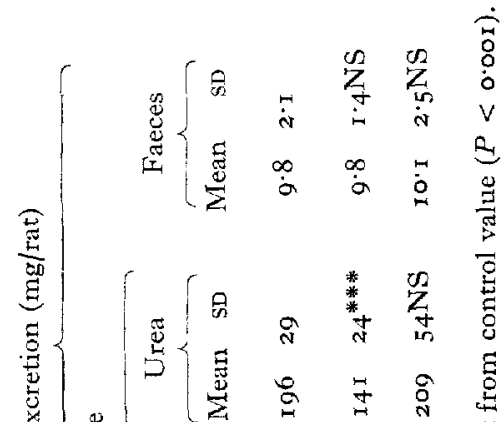

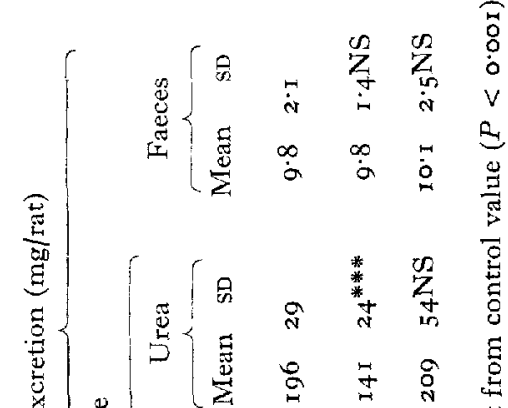

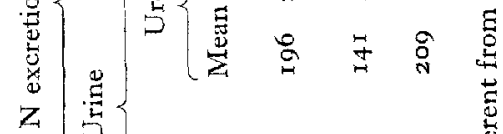

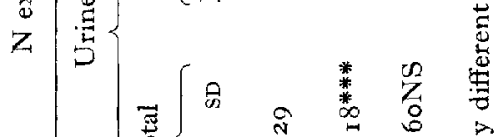

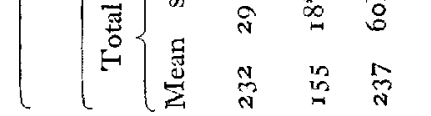

空

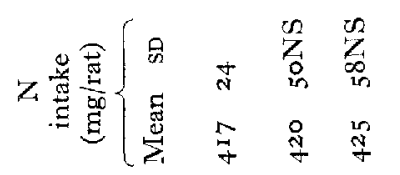

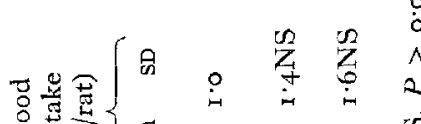

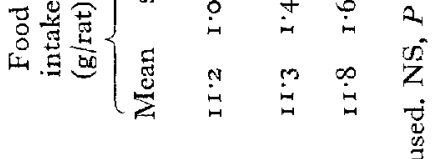

3

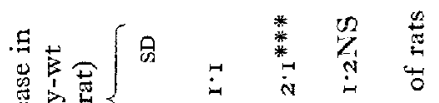

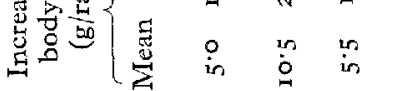

离

To

ह

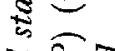

䟢

छ

$\stackrel{2}{2} \div$

呕

辛

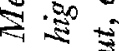

$\therefore \otimes \frac{8}{8}$

-1
0
0

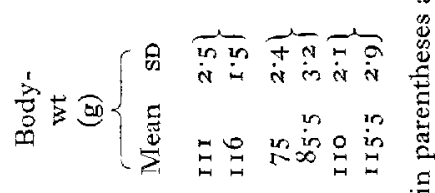

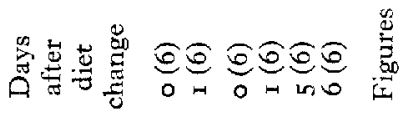

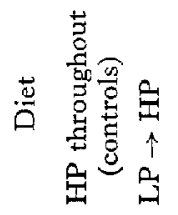


Table 2. Mean values and standard deviations for total, trichloroacetic acid (TCA)soluble and TCA-insoluble nitrogen contents of rats fed on a high-protein $(H P)(250 \mathrm{~g}$ casein $/ \mathrm{kg})$ after $7 \mathrm{~d}$ on a low-protein $(L P)\left(5^{\circ} \mathrm{g}\right.$ casein $\left./ \mathrm{kg}\right)$ diet and in rats fed on the $H P$ diet throughout, expressed as $\mathrm{mg} / \mathrm{g}$ rat

\begin{tabular}{|c|c|c|c|c|c|c|c|}
\hline & Days after & Tota & & TCA-s & oluble N & TCA-ins & luble $\mathrm{N}$ \\
\hline Diet & diet change & Mean & $\mathrm{SD}$ & Mean & $\mathrm{SD}$ & Mean & so \\
\hline HP throughout (controls) & $\circ$ & $26 \cdot 2$ & 0.7 & x.95 & 0.09 & $24 \cdot 3$ & $0 \cdot 6$ \\
\hline & $\mathbf{I}$ & $26 \cdot 4$ & 0.8 & I 93 & 0.10 & 24.5 & 0.8 \\
\hline $\mathrm{LP} \rightarrow \mathrm{HP}$ & o & 25.7 & 0.9 & $\mathrm{I} \cdot 86$ & 0.10 & $23 \cdot 8$ & I.O \\
\hline & $\mathbf{I}$ & $25 \cdot 3$ & 0.6 & $2 \cdot 05$ & $0.06 * * *$ & $2 \cdot 3 \cdot 3$ & 0.7 \\
\hline & 5 & $26 \cdot 0$ & $I \cdot 2$ & $I \cdot 90$ & 0.10 & $24^{\cdot 1}$ & $\mathbf{I} \cdot \mathbf{I}$ \\
\hline & 6 & $25 \cdot 9$ & 0.9 & $r \cdot 94$ & 0.08 & 24.0 & 0.8 \\
\hline
\end{tabular}

Five or six rats were used in each group.

*** Mean significantly different from the value on the day before $(P<0.00 \mathrm{r})$.

body-weight of the test rats $24 \mathrm{~h}$ after the diet change was probably associated with the metabolic adaptation of the animals to the LP diet received in the previous $7 \mathrm{~d}$ and to an increase in water (accompanied by sodium) observed by Mendes \& Waterlow (1958). The fact that the rate of increase in body-weight of the test rats was similar to that of controls $6 \mathrm{~d}$ after the diet change suggests that the rats had become readapted to the HP diet after this time.

\section{$N$ balance}

Table $\mathrm{I}$ also shows the amounts of $\mathrm{N}$ retained in the body per $\mathrm{d}$ on the $\mathrm{Ist}$ and $5^{\text {th }}$ days after changing from the LP diet to the HP diet. Faecal $\mathrm{N}$ ranged from $8 \cdot \mathrm{I}$ to $10.1 \mathrm{mg} / \mathrm{d}$ per rat in all groups and was much less than urinary N. Excretion of total $\mathrm{N}$ and urea $\mathrm{N}$ in the urine were strongly affected by the change in diet. $\mathrm{N}$ intake, in $\mathrm{mg} / \mathrm{d}$ per rat, I and $5 \mathrm{~d}$ after the diet change was the same as in control rats. On the other hand, after $24 \mathrm{~h}$ of the diet change, the rats excreted significantly less total urinary $\mathrm{N}$ and urea $\mathrm{N}$ than the controls, but on the 5 th day after the change they excreted the same amount as control rats. Consequently, $\mathrm{N}$ balance was greater than that of control rats $24 \mathrm{~h}$ after the diet change, but not on the 5 th day after the change, in good correlation with the changes in the increase in body-weight.

\section{$N$ determination in the whole carcass}

To examine the nature of the $\mathrm{N}$ retention, total-, TCA-soluble- and TCA-insoluble$\mathrm{N}$ in the whole body were measured (Table 2). All these values, expressed as $\mathrm{mg} / \mathrm{g}$ rat, tended to be lower in rats after $7 \mathrm{~d}$ on the LP diet than in the controls. The contents of total- and TCA-insoluble- $\mathrm{N}$ remained low for at least $24 \mathrm{~h}$ after the diet change but they returned to normal after $5 \mathrm{~d}$. The content of TCA-soluble-N increased very markedly $(P<0.00 \mathrm{I}) 24 \mathrm{~h}$ after the diet change but it had returned to the control value $5 \mathrm{~d}$ after the change. Thus, since the changes in the TCA-insoluble-N content were very small in relation to the changes in body-weight gain, it appears that the protein content of the experimental animals must have increased for $24 \mathrm{~h}$ 
after the diet change at almost twice the rate of the controls and that $5 \mathrm{~d}$ after the change it had returned to normal.

From the results for urinary $\mathrm{N}$ and urea $\mathrm{N}$ excretions and from the determinations of carcass $\mathrm{N}$, it appears that both increased synthesis and reduced catabolism of body protein occurred in the rats during the first $24 \mathrm{~h}$ period after the change to the $\mathrm{HP}$ diet and that they returned to control levels within $5 \mathrm{~d}$ after the change.

\section{Proteolysis}

It still seems uncertain whether it is better to use anaerobic or aerobic conditions for measurement of the true rate of tissue protein breakdown. There are many reports on the release of labelled amino acids from pre-labelled proteins in the liver (Simpson, 1953; Steinberg \& Vaughan, 1956; Schimke, Sweeney \& Berlin, I965; Brostrom \& Jeffay, 1970). It was found that anaerobic conditions and respiratory inhibitors inhibited protein degradation in rat liver slices, indicating that energy may be necessary for protein breakdown as well as protein synthesis. Korner \& Tarver (1957-8) reported that anaerobic conditions and dinitrophenol inhibited the release of radioactive amino acid from the nuclear and mitochondrial fractions but stimulated release from the microsomal fraction. Further, they reported that addition of ATP and phosphocreatine to the incubation medium inhibited release from all the fractions. Recently, Brostrom \& Jeffay ( 1970 ) reported that anaerobic conditions inhibited the release from liver slices but not from liver homogenates. In our experiments, we incubated tissue slices in vitro under anaerobic conditions since these conditions reduce the apparent reduction in protein breakdown due to both protein resynthesis and amino acid degradation. In a preliminary experiment it was found that there were net increases in the amounts of material reacting with the Folin-Ciocalteu phenol reagent when liver slices and homogenates and diaphragms were incubated in vitro at $37^{\circ}$ for $2 \mathrm{~h}$ under nitrogen. To see whether the amounts of individual amino acids increased, these were determined in the medium before and after incubation of liver homogenates and it was found that there were net increases in all the amino acids after incubation.

Results for proteolysis in the liver and diaphragm are shown in Table 3 . Proteolysis in the liver, expressed per $\mathrm{g}$ tissue, was significantly reduced $(P<0.00 \mathrm{I})$ in rats that had received a LP diet for $7 \mathrm{~d}$. This reduced proteolysis in animals on a LP diet appears to be consistent with the findings of Muramatsu, Sato \& Ashida (1963) and Stephen \& Waterlow (1966) that the turnover rate of liver protein was reduced in protein-depleted rats. It is also compatible with the observation of Umaña (1967) that the activities of acid and neutral proteolytic enzymes are low in the livers of protein-depleted rats.

Hepatic proteolysis, expressed either per $g$ of liver or per liver, was significantly lower in rats $24 \mathrm{~h}$ after the diet change than in control rats. However, it was significantly higher than the level before the diet change. Five days after the change to the HP diet proteolysis had nearly, but not completely, reached the control level.

Proteolysis in the diaphragm, expressed per $g$ tissue, was lower in the LP rats than in the controls but after $24 \mathrm{~h}$ on the HP diet it had increased to a value slightly greater than the control value. However, it was significantly lower than the control on the $5^{\text {th }}$ 


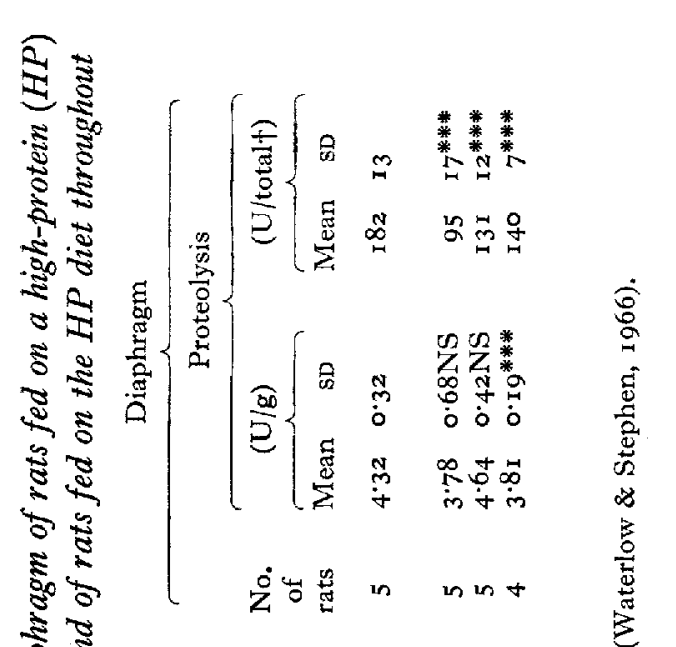

है

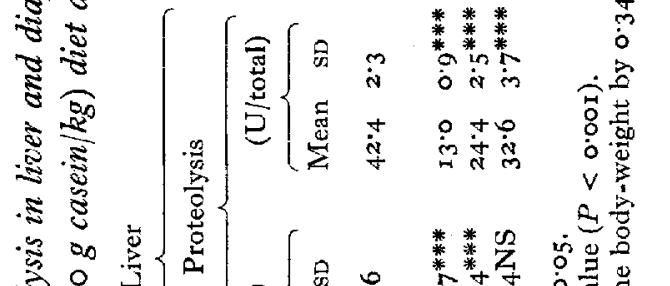

竞造

迥

은

sิ.

㫋

.

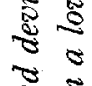

है ริ

จ

究 1

है

胥

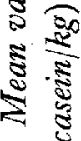

$\dot{n} \operatorname{son}_{0}$

른 은

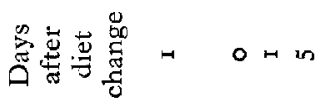

焉

り*世

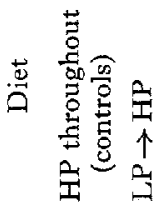

跤

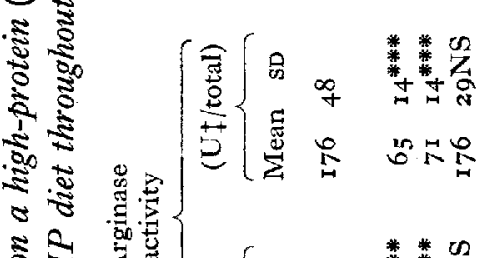

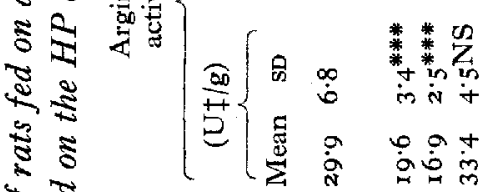

ช

苌各

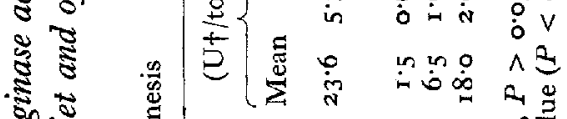

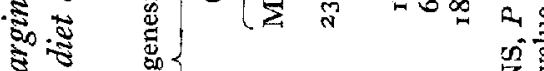

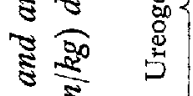

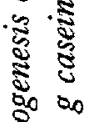

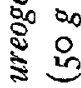

密

골

ड:

.

.

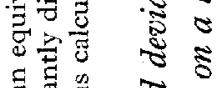

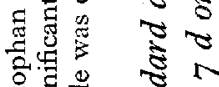

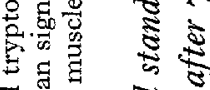

要要要

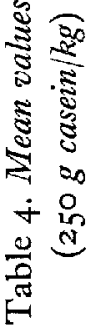

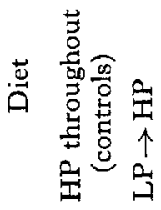


day after the diet change. When expressed per total muscle mass (calculated by multiplying the body-weight by 0.34 (Waterlow \& Stephen, 1966)), it was significantly lower $24 \mathrm{~h}$ after the diet change than in control rats, and $5 \mathrm{~d}$ after the change it still had not increased appreciably (because proteolysis per $g$ diaphragm was low at this time).

\section{Ureogenesis and arginase activity}

Since urea production from amino acids occurs only in the liver (Allison \& Bird, I964), we studied the rate of urea production in liver slices in vitro, incubating them without any substrate.

Table 4 shows that ureogenesis by liver slices, expressed per $\mathrm{g}$ liver or per total liver, was very significantly reduced in rats $24 \mathrm{~h}$ after the diet change and had nearly, but not completely, returned to the control level $5 \mathrm{~d}$ after the change. As shown in Tables $\mathrm{I}$ and 4 , the in vivo rate of urea production $24 \mathrm{~h}$ after the diet change was depressed to a smaller extent in relation to the controls than the in vitro rate of urea production in liver slices on the same day. Further, on the 5 th day, $\mathrm{N}$ and urea excretion in the urine had returned to the control level, whereas ureogenesis in vitro was still slightly depressed. A possible explanation for these results is that urea production occurred in the kidneys as well as the liver, since some arginase activity was detected in the kidney (Ashida \& Harper, 1961) although its level was far below than that in the liver. Therefore, we attempted to measure urea production in slices of kidney cortex, but were unable to detect any. Thus we cannot explain why $\mathrm{N}$ and urea excretion in vivo did not change exactly in the same way as ureogenesis in vitro. However, their changes were roughly correlated.

Arginase activity, expressed per $\mathrm{g}$ liver or per total liver, was the same $24 \mathrm{~h}$ after the diet change as on the day before the change, being significantly lower than that in control rats. On the $5^{\text {th }}$ day after the change it had returned to the control level. Restoration of the hepatic arginase activity in rats $5-7 \mathrm{~d}$ after change from a LP diet to a HP diet or from a HP diet to a LP diet has been reported by Ashida \& Harper (1961) and Schimke (1963). In this connexion Das (1971) reported that adaptation of the enzyme had occurred only $3 \circ \mathrm{h}$ after the change in diet. But in our dietary conditions this was not observed. The low arginase activity observed in this work $24 \mathrm{~h}$ after the diet change, which must have been largely due to the LP diet received previously, may have contributed to the low levels of urea excretion and hepatic ureogenesis for this period.

The results in Tables I, 3 and 4 show that there were rough correlations between $\mathrm{N}$ and urea excretion in the urine, proteolysis and ureogenesis $24 \mathrm{~h}$ after the diet change. Further, $\mathrm{N}$ intake for the day was exactly the same as in the control rats. Thus the increased $\mathrm{N}$ retention observed in rats $24 \mathrm{~h}$ after the diet change appears to be mainly due to the decrease in urinary $\mathrm{N}$ excretion. The reduced proteolysis observed in liver and muscle during this transition period may be associated in some way with the observed reduction in urea excretion. It will also contribute to the increased accumulation of body protein that occurred. 


\section{REFERENCES}

Allison, J. B. \& Bird, W. C. (I964). In Mammalian Protein Metabolism Vol. I, p. 483 [H. N. Munro and J. B. Allison, editors]. New York and London: Academic Press Inc.

Anson, M. L. \& Mirsky, A. E. (1932-3). F. gen. Physiol. 16, 59.

Archibald, R. M. (1945). \%. biol. Chem. 157, 507.

Ashida, K. \& Harper, A. E. (1961). Proc. Soc. exp. Biol. Med. 107, г5 I.

Britton, H. T. S. \& Robinson, R. A. (193I). F. chem. Soc. p. 1456.

Brostrom, C. O. \& Jeffay, H. (1970). F. biol. Chem. 245, 4001.

Das, T. K. (1971). Proc. Nutr. Soc. 30, 79 A.

Horie, Y. \& Ashida, K. (1971). F. Nutr, ror, I319.

Korner, A. \& 'Tarver, H. (1957-8). F. gen. Physiol. 41, 2 I9.

Mendes, C. B. \& Waterlow, J. C. (1958). Br. F. Nutr. 12, 74.

Metz, R., Salter, J. M. \& Brunet, G. (1968). Metabolism I7, I 58.

Muramatsu, K., Sato, T. \& Ashida, K. (1963). F. Nutr. 81, 427.

Schimke, R. T. (1962). F. biol. Chem. 237, 459 .

Schimke, R. T. (1963). F. biol. Chem. 238, rar2.

Schimke, R. T., Sweeney, E. W. \& Berlin, C. M. (1965). F. biol. Chem. 240, 4609.

Simpson, M. V. (1953). F. biol. Chem. 201, I43.

Stein, W. H. \& Moore, S. (1954). J. biol. Chem. 211, 915.

Steinberg, D. \& Vaughan, M. (1956). Archs Biochem. Biophys. 65, 93.

Stephen, J. M. L. \& Waterlow, J. C. (1 966). Nature, Lond. 211, 978.

Umaña, R. (г 967). Archs Biochem. Biophys. I19, 526.

Waterlow, J. C. \& Stephen, J. M. L. (I966). Br. F. Nutr. 20, 46 I. 